\title{
Reflection and Exploration on the Innovations of College Students
}

\author{
Xie Fangwen \\ (Liaocheng University Shandong Liaocheng 252059)
}

\begin{abstract}
Key words: college student's innovation practice
Abstract: 21st century is the age of knowledge -economics, whose soul is "innovation". The country which has the high quality talents will have initiative in the world. The new situation brings not only the new challenges but also the new topics to the colleges and universities which mainly cultivate high-quality innovative talents. To drive passion by training, to improve technology by match, to strongly stimulate students interest and potential, and to cultivate students' creative consciousness, creative thinking, and entrepreneurial ability and the team collaborative combat spirit is a key link and basic content of establishing the university innovation system.
\end{abstract}

\section{Introduction}

The 21 st century is full of the competition in economy and the comprehensive national strength, which is actually the competition of science and technology and education. But in the final analysis, it is the competition in high quality talented person. To improve the student's awareness of innovation, creativity and entrepreneurship, and cultivate college students' innovative undertaking ability is a key link and the basic content o establish the university innovation system, which will strengthen college students' entrepreneurial ability, and promote the comprehensive qualities of college students.

\section{The pursuit of the innovation in the practice of innovation}

First, in the innovative practice the undergraduates should learn theory, establish ideal and have pursuit.

Ask the college students to learn theory, but it doesn't mean recite the book and move others set of theory and practices. It means master the theory and the essence of socialism with Chinese characteristics, and establish a scientific way of thinking, especially make the theory rooted in ones mind to become the people's ideals, beliefs, pursuit,thinking and behavior, through ones efforts to come true the public ideal of make more people live better. Be a person who insist pursuit in noble life, make a significant contribution in pioneering the practice and theory creation.It should also learn to master the latest theories and methods of related disciplines. Interdisciplinary topics, and when the polytechnic students do the liberal arts subjects, they should learn master the basic theories and methods of related disciplines.

\section{College Students' innovative practice}

Second, The undergraduates should make the innovation practice through the social reality, and get the correct understanding of micro Chinese.

The research of social science is to explore the logic and effective way of the development of human society. The thorough, systematically and real survey and grasp of the reality and the development process of society, is the foundation and source of all successful works.Because of exam-oriented education and teaching reform which is not in place, undergraduates know too little 
about change of society, urban and rural, and people life. Much is indirect, and even distorted. To participate in the challenge cup,undergraduates go into the social reality and life, and get in-depth and specific knowledge of the development and change of the society, and the people actual creation.It is not only to get first-hand materials to finished product accumulation, but also to improve their understanding of society and the actual work ability.Competition process proved that,repeatedly, the work get the higher prize, its research is done solidly and in depth.

4、 make bold innovations during the process of innovation practice

Third, undergraduates should learn to think independently and make bold innovations during the process of innovation practice.

Adhere to independent thinking, free spirit is the rode to success of all the academic research. Since China's reform and opening up, from the thought and the development ideas, Countries can create wonders for the world is due to persist the thought of seeking truth from facts and keep pace with the times, the spirit of think independently and innovation, persist in learning and catching up with others.

The new generation of college students must have this scientific thought. China has many special history and national conditions, such as five-thousand year old culture, the unbalance development; the population is larger than the sum of Europe's and north and south America's population; China's process of industrialization, modernization and internationalization were carried out under the leadership of communist party of the socialist system. We shouldn't obtain existing answers from Marxism and copy western theories and solutions.

So,contemporary undergraduates need to use the principle of realistic,keep pace with time and independence, propose new concepts, new knowledge, new ideas boldly. This should be a kind of modern college students' pursuit, a way of thinking and a kind of research approach.

5、 try to change the world

Fourth, the innovation practice of undergraduates should learn to meet practical needs, and try to change the world.

College students in the social investigation practice will meet various specific problems and contradictions, and even unfair or unreasonable things. They will try to contact, understand and do some study, but this is far from enough, the important thing is to change the world, the college student should try their best to solve them. With a thinking and pursuit of change the world, to carry out some activities that the students can join in their power to solve the problems, is the innovation practice activities of the leap from to know the world to to change the world, and the actual performance of innovation.

Fifth,in the innovative practice the undergraduates should strengthen the team cooperation and the collaborative research.

Research is necessary for college students to strengthen their team cooperation sprite in innovation practices because complicated problems about the development and reform of modern society were often solved by those teams that shared the same idea, had reasonable distribution of subjects and worked divided and cooperative. Team cooperation not only can complete large projects, but also can train students' organization ability, leadership, coordinate ability and leaders. Team activities, not merely need unity, cooperation, coordination and complementary, but also need mutual division of labor, full discussion and mutual encouragement. These are organizational conditions of successful innovation practice.

Sixth, in the innovative practice the undergraduates should establish a rigorous style of study and stick to the academic norms .

College students should establish a rigorous style of study and stick to the academic standard in 
innovation practice though it is difficult to completely avoid these phenomenons of impetuous, speculation, misconduct, plagiarism, plagiarism in academia under the condition of reform and opening up, market economy.From the view of humanities and social science, it is necessary to establish people oriented ideas and feelings and form the atmosphere of going deep into practice, masses and life. This is the style of study guarantee of successful innovation practice.

Practice activity on Innovation not only develops and cultivates the consciousness of college students' innovation, creativity and entrepreneurship, but also improves the ability of innovative undertaking.

\section{References}

[1] Jiang Kan, Wei Zhaowen, Deng Ke. Explore and Research on Undergraduate Innovation Practice[J],High Education Forum, Aug.2007.No.4:129-131.(in Chinese)

[2] Zhao Qingnian. Develop the Innovations and Training the Students' Ability[J], Journal of National Academy of Education Administration,

[3] Guo Li, Wang Xunan, Wang Han,Xia Hailan,

[4] Zheng Chunlong.Reflection and Exploration on Training the innovation Ability of College Students[J],China University Teaching,

[5] Zhang JinHua. Reflection of Local Colleges Comprehensive push on Undergraduate Innovation Education[J],China Adult Education, 